\title{
The Economic Impact of COVID-19 on the Omani Tourism Sector Author $1^{1}$ Zakiya Salim. Al-Hasni
}

${ }^{1}$ Universiti : Warsaw School of Economics, Warsaw, Poland

*author1za65806@doktorant.sgh.waw.pl

\begin{abstract}
The COVID-19 pandemic has continued to cripple the tourism sector globally. The Omani tourism sector is not an exception. However, there are no empirical studies focusing on how Oman's tourism sector has been affected by the COVID-19 pandemic. This study aimed to analyze the economic effect of COVID-19 on Oman's tourism sector. The study sought to achieve three specific objectives, namely, to find out the economic effect of COVID-19 on the number of tourists visiting Oman, to analyze the variations in the amount of tourism into Oman since the COVID-19 became a global health threat and to evaluate the effectiveness of the strategies that Oman is implementing to cushion the tourism sector from the economic effects of COVID-19. A secondary data methodology was adopted, which involved collection and analysis of data from already published sources. Inclusion/exclusion criteria of relevance, up-to-date and author credibility were used to select the sources of information to be used. Both qualitative and quantitative data was collected and analyzed. Findings from the study revealed that COVID-19 has orchestrated the decline in the performance of Oman's tourism industry. There has been increased unemployment, reduced incomes and falling consumer purchase power. It is recommended that the Oman government develop and implement policies that reduce tax burden on tourist organizations and give tourist firms stimulus packages to cushion the sector from collapsing due to the effects of COVID-19.
\end{abstract}

\section{Keywords}

COVID-19 pandemic, tourism sector, Omani economy

\section{Introduction}

The economic impact of the COVID-19 pandemic on the global tourism industry continues to attract widespread interest from both scientific research and practice. The Coronavirus Disease 2019 (COVID-19) emerged from Wuhan City, Hubei Province in December 2019 before developing into a global health threat in 2020 (Lau et al., 2020; Altuntas \& Gok, 2020). The World Health Organization declared COVID-19 a pandemic, a step that necessitated the initiation of movement restrictive measures as part of the effective methods to reduce its spread. O'Mahony (2020) identifies that due to its dependence on inter-regional flow of people, the performance of the tourism industry has exhibited a downward trend since the COVID-19 was declared a pandemic. Regardless of the unprecedented interest in research to decipher the economic effects of COVID-19 on the tourism sector, region-specific empirical studies focusing on high performance tourism countries such as Oman are still limited.

The COVID-19 pandemic has halted the economic gains that Omani has realized in its tourism industry or sector. Understandably, the ban on international travel as a strategy to contain coronavirus has halted tourism activities (Sah et al., 2020). For instance, hotels, national parks, and other attraction sites and tourism services have been closed. The ramification for this has been lack of visitors and loss of revenue and employment in the Omani tourism sector. Typically, the coronavirus pandemic has slowed down Oman's economic growth by decimating visitors to the country, tourism-related jobs, and consequently reducing the country's productivity. Notwithstanding the widely observed economic effects, there are no scientific studies that have combined scientific evidence that empirically analysed the effect of COVID-19 pandemic on Oman's tourism sector. This study aims to contribute to literature of Oman regarding the economic impact of COVID-19 on its tourism sectors and generate information that the players in the tourism sector, managers and the government can use to reformulate their policy frameworks in order to ascertain the sustainability of Oman's tourism sector.

\section{Research Aim}

The aim of this study is to analyze the economic effect of the COVID-19 pandemic on the Oman tourism sector.

\section{Objectives}

1. To find out the economic effect of COVID-19 on the number of tourists visiting Oman.

2. To analyze the variations in the amount of tourism into Oman since the COVID-19 became a global health threat.

3. To evaluate the effectiveness of the strategies that Oman is implementing to cushion the tourism sector from the economic effects of COVID-19.

\section{Research Questions}

1. What is the economic effect of COVID-19 on the number of tourists visiting Oman?

2. Has the amount of tourism changed since the COVID-19 was declared a global health crisis?

3. How effective are the strategies that Oman is implementing to cushion the tourism sector from the economic effects of COVID-19?

\section{Conceptual Framework}

Figure 1 below is a diagrammatic representation of the conceptual framework for this study that links the independent variable (the COVID-19 pandemic) and the dependent variable (performance of the tourism sector). 


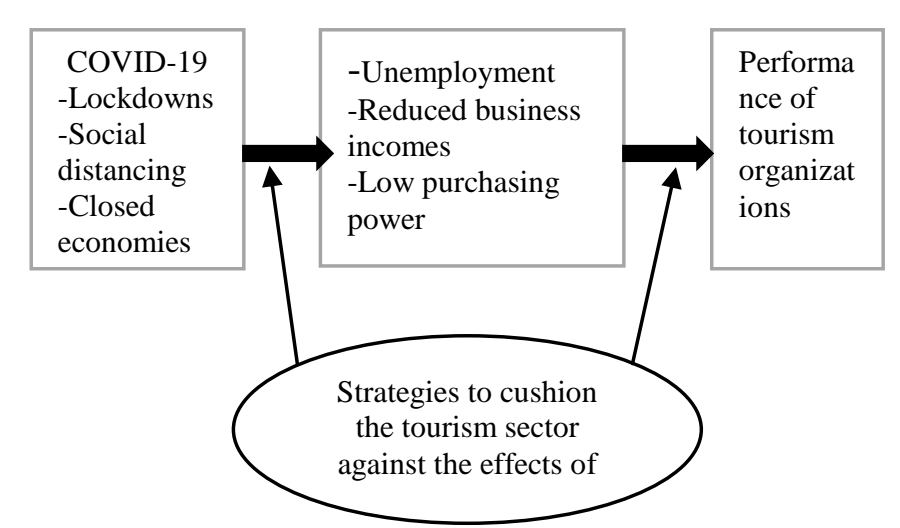

Figure 1: The conceptual framework (Source: Author, 2020)

The conceptual framework for this study in figure 1 above is based on the prediction that the COVID-19 pandemic affects the Oman economy through reduced employment opportunities, revenue generation and people's purchasing power. This eventually affects the performance of the tourism sector. The framework also seeks to evaluate the extent to which the strategies to cushion the tourism sector against the effects of COVID-19 have been effective.

\section{Theoretical Framework}

The theoretical framework for this study is founded on the tenet that tourist organizations can encounter challenges that interfere with their performance. The most suitable theoretical framework to explain the performance of tourism in Oman in the context of COVID-19 is Butler's Tourist/Destination Area Lifecycle (TALC) as illustrated in figure 2 below.

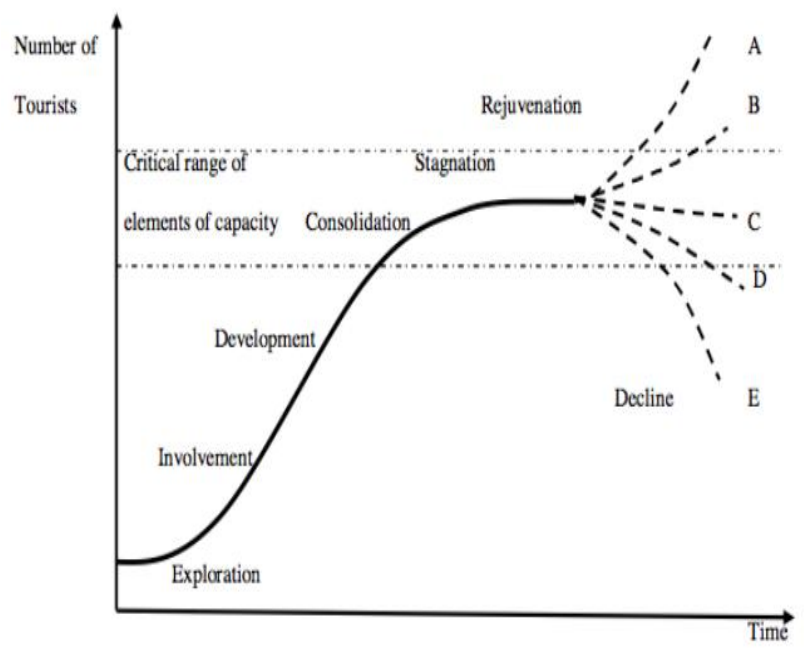

Figure 2: Butler's Tourist/Destination Area Lifecycle (TALC) (Source: Piuchan, 2018) consolidation, and stagnation/rejuvenation (Singh, 2020) The final stages has two alternatives, which are rejuvenation or stagnation as indicated by letters A-E in figure 2 above. Letter E shows a sharp decline, implying that the amount of tourism sharply reduces. According to Piuchan (2018), the causes of such sharp decline include war, catastrophic events and diseases. The framework is relevant to this study because it depicts how diseases such as the COVID-19 can negatively affect tourism performance.

\section{Literature Review}

Several studies have strived to elucidate how tourism impacts the economy of countries. However, most studies have failed to examine how pandemics, particularly the public health crisis, have economic implications on the tourism sector of countries. For example, the study by the OECD in Junior et al. (2019), going by the comprehensive statistics, estimates that there has been a $60 \%$ decline in the international tourism practice. With the continuing pandemic, this data is predicted to rise to $80 \%$ by December 2020. Domestic Tourism, which accounts for up to $75 \%$ of tourists in most countries, is also affected due to restriction of movement and stayat-home orders. Despite the report's elaborate discussion of coronavirus and tourism economy of OECD, it has scanty information on Oman.

Taylor (2020) sought to examine the coronavirus situation on the country's tourism and economy. This source explains that Oman needs to cushion players in the tourism industry to avoid the negative implications of coronavirus. Oman News Agency proposes bilateral talks between the minister of tourism and other stakeholders in the tourism sector. The major stakeholders and affected individuals, in this case, include the owners of hotel establishments within the economy as well as employees within the tourism sector. In the conferences conducted by these stakeholders, there was a critical point of resolving that the challenges raised by the approaches that the governments, as well as visitors, had taken to combat the problem affected the economic perspective of the country's tourism sector significantly. However, the source does not illustrate how coronavirus pandemic affects the economy of the Omani tourism industry.

Based on the model, tourism development goes through six stages, namely, exploration, involvement, development, 
According to the United Nations World Tourism Organization (2020), there is a prediction that the international tourist arrivals to various destinations may decrease by about 20 to $30 \%$, which is predicted to rise to $60 \%$ by December 2020. In most of the countries, altogether, people traveling to and from the nations have gone own by up to $90 \%$. This source credits limited people's ability to engage in tourism activities to restrictions on social gatherings. These restrictions force people to avoid places such as museums, amusement parks, and sports venues, which are key tourist attraction avenues. Although this source helps people to have a wider scope on the effects of coronavirus on the tourism sector and economy, it lacks specificity.

Regardless of the importance of the tourism sector in Oman, some studies on COVID19 have focused on different industries. For example, Al Amri and Marey-Perez (2020) studied the impact of COVID-19 on Oman's construction industry while Wiwanitkit (2020) focused on the levels of infection of COVID-19 in Oman and found out that infections were mild $(95.9 \%)$, moderate $(3.6 \%)$ and severe $(0.5 \%)$. This implies that there is a gap in empirical research regarding the economic effect of COVID-19 on tourism performance. Going by the tenets of Butler's Tourist/Destination Area Lifecycle, diseases can lead to a sharp decline in tourism. Confirming the tenets of the model, Škare, Soriano and Porada-Rochoń (2020) established that the COVID-19 pandemic subjected the tourism industry to a destructive impact that will take more time to recover than an average period of 10 months as previously expected. However, the study focused on 185 countries using past data. The current study seeks to use real-time data to decipher the economic effect of COVID-19 on Oman's tourism sector.

\section{Research Methodology and Data}

This study adopted a secondary research methodology, which involved collection and analysis of data from the already published sources of information focusing on the economic implication of coronavirus pandemic on the Omani tourism sector. The sources used for the research included press conferences reports, news articles from credible media, books, journal articles, and credible internet sources. These sources are obtained from credible online libraries and databases such as Google Scholar, EBSCOhost, and ProQuest, government websites and reliable publications.

The inclusion/exclusion criteria was used to select the sources of information for this study. The criteria included up-to-date, relevance and credibility. The year of publication was limited to the past five years (2015-2020. Relevance involved ascertaining that the sources of data are focusing on the themes of economic effects of COVID-19 and tourism performance of Oman. This was achieved using the keywords and phrases including "the Omani tourism sector," "COVID-19 pandemic and Omani tourism sector," and "economic implications of COVID19 on the Omani tourism sector," and COVID-19 in Oman. Notably, all the sources selected for this study were authored by scholars with impeccable credentials in their professional fields.

The nature of data collected was both qualitative and quantitative. The analysis of qualitative involved reiteratively reading identified sources to search for differences and similarities in their contents on the Omani tourism economy in the wake of coronavirus pandemic. The economic outcomes and implications of coronavirus in the Omani tourism sector were noted down and sorted to find themes. Quantitative data was subjected to mathematical manipulations to ensure that datasets make sense and exhibit relevance to the aim of this study. Presentation of the results was done using tables, graphs and charts.

\section{Empirical Research Result}

Tourism is one of the leading non-oil sector contributors to the GDP of Oman that contributes to income and employment opportunities for Omani citizens (Al Maamari, 2020). Moreover, the tourism sector enables Oman to earn significant amounts of foreign exchange and activates infrastructural development, which economically empowers citizens and the country. According to Searle 
(2019), Oman has many tourist sites such as Wadi Ash Shab and Jebel Shams, which attract many visitors throughout the year. Oman has significant developments in tour agencies, operators, as well as car rental services, which all develop as complementary services to the aspect of tourism and travel within the nation (Al Omar, 2019). In this regard, tourism contributes significantly to the economy of the country. The report by the UNCTAD. (2018) reveals that tourists and travel industry contributed to $9.8 \%$ of Omani GDP in 2015, which rose from $3.7 \%$ in 2014. Therefore, this report indicates growth rates within the Omani tourism sector that economically benefit the government and its people.

The Omani tourism sector could become a key player in the global tourism market in a few years. Oman's tourism sector contributes $2.8 \%$ to the GDP. On top of this, the direct added value that was generated by Omani tourism sector was RO 505 million (about US\$ 1.3 billion) in 2009 and RO 719 million in 2017 (about US\$ 1.8 billion) (Taylor, 2020). These statistics put the sector as the second contributor to the country's economy after the lucrative oil industry. The tourism sector raises capital to the government, provides employment to Omani citizens, and improves the country's infrastructure. As already mentioned, the tourism industry is the secondlargest source of employment and the leading nonoil industry employer in Oman. It employs up to 72,500 people, which is about $3.4 \%$ of the national workforce. The number of people employed in the Omani tourism sector was predicted to rise to $6 \%$ by the year 2021 if it was not for the coronavirus pandemic. This is evident from the consistent increase in the number of tourists visiting Oman between 2005 and 2017 as shown in figure 3 below.

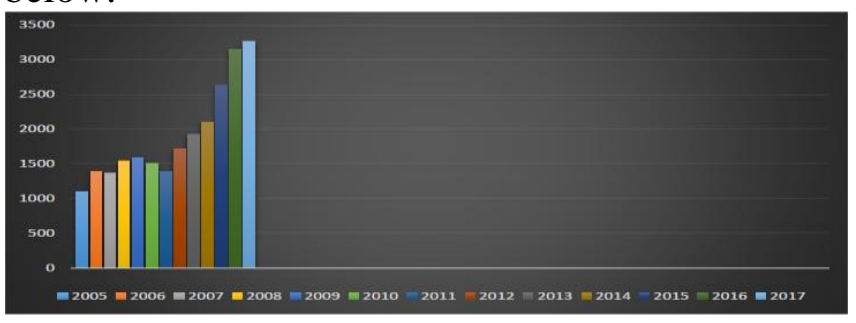

Figure 3: Trends in the number of visitors arriving at Oman between 2005 and 2017(Source: Omari, 2019)
The year 2019 saw the Sultanate of Oman welcoming more than 3.5 million tourists, which was a $18.14 \%$ increase from 2018 (Tatiana, 2020). PwC (2020) revealed that there was a 7\% increase in the amount of tourism to Middle East to 64 million visitors. However, by the end of the first quarter of 2020, the Middle East had experienced an $11 \%$ decline in the number of tourists visiting the country's sites. Restaurants and hotels that depend on tourists have also had to be closed due to low demand. The few hotels that have remained open have had to incur losses because of the coronavirus containment guidelines (UNWTO, 2020]. Admittedly, the guidelines have forced hotels to operate at half or a quarter of its capacity. For this reason, hotels and other eateries have had to fire some employees to reduce their wage bill. Tourist attraction sites such as museums and national parks that depend on tourists for revenue have had to reduce their workforce as their wage bill has become unsustainable. With lost income, the jobless tourism sector employees have experienced hard economic times.

Travel agencies, hotels, and restaurants are some of the most basic support industries in the practice of tourism. According to Atsalakis, Atsalaki and Zopounidis (2018), without tourism, these industries are deemed to be non-existent as they cumulatively make up the tourism sector. As such, the development of such industries in any nation world indicates the increasing economic potential and skills within the country. COVID-19 has largely affected these support industries. This pandemic has led to decreased revenue generation among tourism support industries. Taylor (2020) elucidates that the traveling agencies, including the airline companies and the tour guides within Oman, have experienced negative economic implications due to coronavirus. In particular, the support industries have recorded losses for the first two quarters of the year as they have barely had economic activity taking place. Hence, for operational support industries, their revenues have been used to meet their overhead and running costs amidst minimal or no work.

In Oman, the ravaging coronavirus pandemic has made the number of travelers using airline services to fall by around $89 \%$ in Oman 
between December 2019 and March 2020. Furthermore, Omani travel agencies and hotel restaurants have recorded a fall of about $75.6 \%$ and $78.4 \%$ (Taylor, 2020). This indicates the drastic fall in revenue for Omani tourism support industries have an overall effect on the country's economy. It is also imperative to explain that the economic crisis of the Omani tourist sector has been further heightened by the proposals to levy $4 \%$ to the hotel clients and customers by the government to ensure that it may raise sufficient revenue for sustenance. While this may avert the impacts felt by the government, it is detrimental to the economic recovery within the hotel and restaurant industry due to raised costs. Thus, few domestic or international tourists are forced to seek alternatives to avoid meeting these additional costs set by the Omani government.

COVID-19 has led to the shrinking of Omani GDP as the tourism sector, which is the second contributor to the country's GDP, has been halted by the pandemic. The loss of revenue due to the near-zero operation of the Omani tourism industry has affected the country's government's ability to fund its activities and operations. Other than the direct loss of revenue due to halted tourist activities, the Omani government also must provide incentives and tax reliefs to players in the tourism sector to cushion them from the pandemic. As the Omani government cushions its citizens, it loses revenue, which it could have used to develop other sectors of the economy. As an illustration, the government has resolved to desist from collecting charges for July to September from tourist agencies within the country to help them cope with the hardships brought by COVID19. With inadequate revenue raised, the Omani government is unable to fund and run some of the major projects that are designed to benefit the people. The government's retraction from some of its key projects earmarked for this year explains the devastating economic effect on the Omani tourism sector.

The country's hotel occupancy has experienced a $32 \%$ drop due to COVID-19. The number of guests registered at various Omani hotels has dropped significantly. Illustratively, the number of guests in Omani hotels decreased by $53 \%$ in the past six months (Taylor, 2020). This has affected the industry's ability to raise revenue for itself as well as for the government. Local Omani hotels have had reported a drop in their revenues for the first half of 2020. Three-to-fivestar category Omani hotels have registered a $\$ 145.2 \mathrm{~m}$ revenue loss, which represents a $51.5 \%$ drop in revenue compared to 2019 .

The air travel industry, which is a tourism support sector, has lost billions of dollars. It is estimated that the Omani government will lose $\$ 0.7$ billion in passenger revenue [Taylor, 2020]. The revenue loss is due to 4.3 million fewer air passengers because of coronavirus pandemic. Moreover, 51,500 jobs in the air travel industry are at great risk of being lost as companies downsize to remain afloat. Overall, with ravaging pandemic and no vaccine to restore normalcy in the world, it is estimated that the Omani economy will lose $\$ 1.7$ billion from its air travel industry.

The government has instituted regulations and policies that help industries mitigate the economic blow they face. The Omani government has provided tax relief and incentive to cushion its tourism sector. Nonetheless, it has instituted other policies that include additional charges to raise more revenue. However, on top of changing the government's ability to meet its economic obligations, it affects the ability to complete projects that would provide the country with a better economic environment. The finances that the government has put into mitigating and dealing with COVID-19 would, in normal conditions, be used to improve the situation of the people hence improving their economic potential and facilitating growth for the whole country.

\section{Research Limitations and Further Areas of Research}

One of the limitations of this study is that is adopted a secondary methodology, which is subjected to possibilities of collecting obsolete data. Moreover, reliability and validity of data from secondary sources may also be demeaned by possible transfer of biases that characterized original studies. Although the researcher screened sources of data for relevance and credibility, findings from the study may not be readily generalizable to large populations of tourist 
destinations because of the shortcomings of secondary sources. Regardless of this, the sources provided sufficient sources for this study being an academic study. Future researchers may consider using primary sources to collect both qualitative and quantitative data in order to enhance the validity, reliability and generalizability.

\section{Conclusion}

This study sought to investigate the economic impact of COVID-19 on the tourism sector of Oman. The study adopted a primary data methodology, which involved use of secondary sources to extract information relating to trends in Oman's tourism during the COVID-19 pandemic period. Findings from the study revealed that the restrictions for curbing COVID-19 have significantly affected the performance of Oman's tourism industry.

The study showed that COVID-19 has led to massive job losses and loss of revenue in the Omani tourism sector. Players in the tourism sector, such as air travel, parks, museums, and hotels, have had to downsize the number of

\section{Implications of the Study}

The failing tourism sector of Oman due to coronavirus pandemic has written off the gains the country has made over the years. The massive job losses in the tourism industry have negative ramifications on the economic wellbeing of Omani citizens that depended on it for their livelihood. It will take time before Oman can revive its tourism economy as an attractive venture for both people coming to the country in search of sites where they can enjoy their holidays as well as those who go to these countries in search of job opportunities. Presently, the failing tourism sector implies that Oman relies on its citizens as the only source of capital to finance government projects. This leads to high taxation of citizens, leading to low living styles and the quality of life of Omani people. For this reason, Omani people have no disposable income to engage in leisure activities due to hard economic times imposed by the coronavirus pandemic. employees to avoid high expenditures on salaries. These players have also received few visitors as people have avoided them willingly or forcefully by established guidelines to combat coronavirus pandemic. The ramification for this has been low occupancy of hotels and restaurants, low visitation of tourist attraction sites, and few passengers for flights, but to mention a few. As a result, the Omani tourism sector has lost billions in revenue. Its employees have also lost their source of livelihood, which has impacted their socioeconomic welfare and wellness.

The Omani government also has been forced to offer tax reliefs to tourism sector players. It has also cushioned them by giving stakeholders in this industry financial incentives. Thus, these strategies or initiatives have crippled the overall economy of Oman. The move by Oman to cut out some of its budget of the government agencies is an indicator of its pursuit to address the economic fallout caused by the virus. Overall, the Omani government should be steadfast in establishing guidelines that will not only combat coronavirus but also revive its tourism industry.

Tourist Organizations in Oman need to start working on their efficiency in order to attract more tourists. Oukil, Channouf and Al-Zaidi (2018) studied 58 hotels in Oman and found out that they are technically inefficient, but most of the efficient hotels are located in Muscat, Oman's capital. Low levels could extend to recovery period than expected. Furthermore, Enzenbacher (2019) found out that the governorate's environment has the potential to yield multiple benefits that can increase Oman's appeal to tourists beyond the Khareef season. Similarly, the providing new forms of food tourism may help rapidly restore tourism immediately after the COVID-19 pandemic is managed.

\section{Acknowledgement}

I am very proud of myself, because in a short time I was able to write a lot of topics in various articles for a juournal, it was very difficult experience went through every page with in-depth research and reviews. Moreover, the quality this work is due to the most important contributions 
from people important to me who have been supported to complete working hard and sharing some good ideas, to which I owe a lot of gratitude and appreciation. I would like to thank all I've had a decent family, especially my dear mother who has a role in my life. For their tremendous support by providing prof a favorable work environment for me to complete this task the level you have reached. Many of my family, friends, co-workers, and anyone else support this process either directly or indirectly.

\section{References}

[1] Al Amri, T., \& Marey-Perez, M. (2020). Impact of Covid-19 on Oman's Construction Industry. Technium Social Science. Journal, 9, 661-672.

[2] Al Maamari, G. (2020). Multiple stakeholders' perception of the long-term success of project: a critical study of Oman tourism resort projects (Doctoral dissertation, Bournemouth University).

[3] Altuntas, F., \& Gok, M. S. (2020). The effect of COVID-19 pandemic on domestic tourism: A DEMATEL method analysis on quarantine decisions. International Journal of Hospitality Management, 92, 102719.

[4] Atsalakis, G. S., Atsalaki, I. G., \& Zopounidis, C. (2018). Forecasting the success of a new tourism service by a neuro-fuzzy technique. European Journal of Operational Research, 268(2), 716-727.

[5] Enzenbacher, D. J. (2019). Exploring the food tourism landscape and sustainable economic development goals in Dhofar Governorate, Oman. British Food Journal, 122(6), 1897-1918.

[6] Junior, A. C., de Godoy Moreira, A., de Souza, C. G., de Oliveira, P. S. G., \& de Oliveira, S. L. I. (2019). Buying Decision: The Choice of Restaurants to Have Dinner. E-review of Tourism Research, 16(5), 457-488.

[7] Lau, H., Khosrawipour, V., Kocbach, P., Mikolajczyk, A., Ichii, H., Schubert, J., ... \& Khosrawipour, T. (2020). Internationally lost COVID-19 cases. Journal of Microbiology,

\section{Immunology and Infection. https://www.sciencedirect.com/science/article/pii/S $\underline{0278431920302711 \text { \#bib0235 }}$}

[8] O’Mahony, B. (2020). Adapting to tourism trends in Hoi An: the challenge for Nam Long restaurant. Asia Pacific Journal of Tourism Research, 25(10), 1071-1084.

[9] Omari, B. K. A. (2019). Tourism Economics In Oman: Astatistical Study For The Period 20002017. Global Scientific Journals, 7(3), 301-313.
[10] Piuchan, M. (2018). Plog's and Butler's models: A critical review of Psychographic Tourist typology and the Tourist Area Life Cycle. Turizam, 22(3), 95-106.

[11] PwC (2020). Impact of COVID-19 on the Philippine Tourism industry. Retrieved from https://www.pwc.com/ph/en/publications/tourismpwc-philippines/tourism-covid-19.html Sah, R., Sigdel, S., Ozaki, A., Kotera, Y., Bhandari, D., Regmi, P., ... \& Dhama, K. (2020).

[12] Impact of COVID-19 on tourism in Nepal. Journal of Travel Medicine, 27(6), 105-116.

[13] Searle, M. (2019). Geology of the Oman Mountains, Eastern Arabia. Springer.

[14] Singh, S. (2020). Time, tourism area 'lifecycle,'evolution and heritage. Journal of Heritage Tourism, 1-12.

[15] Škare, M., Soriano, D. R., \& PoradaRochon, M. (2020). Impact of COVID-19 on the Travel and Tourism Industry. Technological Forecasting and Social Change, 120469.

[16] Tatiana, R. (2020). Oman welcomes over 3.5 million visitors in 2019. Retrieved from https://www.traveldailynews.com/post/omanwelcomes-over-35-million-visitors-in-2019

[17] Taylor, J. (2020). 'Completely dropped': Oman tourism industry braces for coronavirus crisis.

Retrieved from https://www.theguardian.com/world/2020/feb/11/c ompletely-dropped-off-australias-tourism-industrybraces-for-coronavirus-crisis

[18] Wiwanitkit, V. (2020). COVID-19 Infection in Oman. Oman Medical Journal, 35(5), 186-198. 